\title{
Strategi Pengambilan Keputusan Kedai Kopi
}

\author{
Nawangsih ${ }^{1}$, Kurniawan Yunus ${ }^{2}$, Khoirul Ifa ${ }^{3}$ \\ Program Studi Manajemen, STIE Widya Gama Lumajang ${ }^{12}$ \\ Program Studi Akuntansi, STIE Widya Gama Lumajang \\ Email: lovinawang@gmail.com
}

https://doi.org/ 10.30741/adv.v3i2.474

I N F O A R T I K E L

Tanggal masuk :

30 Oktober 2019

Tanggal Revisi :

12 Desember 2019

Tanggal Diterima :

31 Desember 2019
A B S T R A K

Penelitian dilakukan untuk mengetahui pengaruh kualitas produk, harga, promosi dan kualitas layanan baik secara parsial maupun simultan terhadap proses pengambilan keputusan konsumen dalam memilih warung kopi di Kabupaten Lumajang. Jenis penelitian yaitu deskriptif menggunakan pendekatan asosiatif kausal. Penelitian dilakukan membutuhkan sekitar 100 responden. Teknik pengambilan sampel penelitian adalah Simple Random Sampling. Uji hipotesis penelitian menggunakan metode analisis regresi linier berganda untuk hipotesis melalui program SPSS 21 for windows. Hasil penelitian ditemukan indikasi jika kualitas produk, promosi dan kualitas layanan berpengaruh positif dan signifikan secara parsial terhadap proses pengambilan keputusan konsumen dalam memilih warung kopi di Kabupaten Lumajang. Sedangkan harga memiliki pengaruh postif tidak signifikan terhadap proses pengambilan keputusan konsumen untuk memilih warung kopi di Kabupaten Lumajang. Secara simultan kualitas produk, harga, promosi dan kualitas layanan berpengaruh positif secara signifikan terhadap proses pengambilan keputusan konsumen dalam memilih warung kopi di Kabupaten Lumajang. Variabel yang diteliti memberikan pengaruh sebesar $54,1 \%$ pada proses pengambilan keputusan konsumen untuk memilih warung kopi di Kabupaten Lumajang dan sisanya dipengaruhi variable lain yang tidak termasuk dalam penelitian ini.

Kata Kunci : Proses Pengambilan Keputusan, Warung Kopi, Lumajang

\begin{abstract}
A B S T R A C T
This study purpose to determine the influency of product quality, price, promotion and quality of service of partially and simultaneously on the consumer decision making process in choosing a coffee shop in Lumajang Regency. This research type is descriptive with a causal associative approach. This research using 100 respondents. The sampling technique used is Simple Random Sampling. Hypothesis testing using multiple linear regression analysis for hypotheses through the SPSS 21 for windows program. Results of the study showed that product quality, promotion and service quality there is a significant positive influency for partially on the decision making process of consumers in choosing a coffee shop in Lumajang Regency. The price of a positive influence is not significant to the consumer's decision making process in choosing a coffee shop in Lumajang Regency. Simultaneously product quality, price, promotion and service quality have a significant positive effect on the decision making process of consumers in choosing a coffee shop in Lumajang Regency. The variables studied affected $54.1 \%$ of the consumer decision making process in choosing a coffee shop in Lumajang Regency and the rest was influenced by
\end{abstract}


another variables.

Keywords: Decision Making Process, Coffee Shop, Lumajang

\section{PENDAHULUAN}

Keberadaan sebuah kedai kopi/coffee shop menjadi alternatif bagi para pecinta kopi, menikmati sensasi kopi dengan cara dan suasana yang berbeda. Suasana yang nyaman didukung tampilan desain yang unik dan instagramable, dengan beraneka jenis varian kopi yang ditawarkan membuat konsumen kopi nyaman berada di kedai kopi. Suasana kedai kopi turut mengalami perubahan dengan berbagai tambahan fasilitas yang ditawarkan, mulai dari adanya mesin ekspresso, wifi dan jenis tampilan kopi yang disajikan kepada konsumen. Kopi sudah menjadi bagian dari budaya sebagian besar masyarakat kita, bahkan menjadi salah satu kegiatan yang rutin dilakukan sebelum memulai beraktifitas. Minum kopi menjadi sebuah trend dengan semakin banyaknya jumlah kedai kopi di berbagai daerah. Kopi bukan hanya identik sebagai minuman yang didominasi oleh golongan tua, melainkan telah berevolusi menjadi beragam jenis dengan tampilan yang unik dan menarik, sehingga generasi muda mulai menyukai kopi. Ketertarikan generasi muda terhadap kopi menjadikan trend permintaan terhadap kopi mengalami peningkatan karena segmentasi pasar lebih luas. Berdasarkan hasil penelitian dari International Coffee Organization (ICO) menunjukkan bahwa nilai peningkatan jumlah konsumsi kopi di Indonesia lebih tinggi dibandingkan daerah lain. Trend kenaikan jumlah permintaan kopi berdasarkan pada platform jual beli pada pasar digital. Berdasarkan survey yang dilakukan pada pembelian online pada transaksi penjualan kopi di pangsa pasar, mengalami peningkatan yang cukup signifikan secara bertahap, dari jumalh permintaan sebesar 40 ribu permintaan produk kopi pada 2016, selanjutnya naik hingga mencapai hampir 120 ribu permintaan produk kopi selama 2017.

Keputusan pembelian yaitu sebuah pertimbangan konsumen dengan didasari oleh beberapa faktor yang erat kaitannya dengan bidang ekonomi. Pada akhrinya mempengaruhi tindakan konsumen dalam mengelola data serta proses pengambilan produk dalam bentuk umpan balik yang diperoleh dari produk yang dibeli konsumen (Alma, 2013). Indikator yang berperan dalam penentuan pembelian konsumen berkaitan terutama bagaimana perilaku pembelian konsumen (consumer behavior) karena selera konsumen memiliki kebiasaan dan minat yang berbeda dalam melakukan aktifitas pemanfaatan produk. Pertimbangan konsumen mengkonsumsi sebuah produk terjadi karena motivasi konsumen. Tahapan pengambilan pertimbangan mengkonsumsi produk adalah proses internal individu terutama yang berperan vital untuk membantu mengetahui dasar pertimbangan konsumen ketika melakukan proes pembelian mereka (Kotler \& Amstrong, 2016). Keputusan pembelian konsumen akan suatu produk diantaranya melihat kualitas dari suatu produk, harga, tempat, promosi, pelayanan dan masih banyak lagi. Penelitian akan keputusan pembelian pernah dilakukan oleh (Zulaicha \& Irawati, 2016), (Soebakir et al., 2018), (Ge et al., 2007), mengatakan bahwa pertimbangan mengkonsumsi suatu didasari oleh beberapa factor yang relevan dengan hal tersebut.

Kualitas produk menjadi dasar utama dalam pertimbangan konsumen menentukan produk yang akan dibeli. Kualitas produk untuk dipasarkan produsen harus yang terbaik serta sebanding dengan selera konsumen. Karena bagi konsumen kualitas produk menjadi alternatif yang dipertimbangkan konsumen, selain dari segi harga, bentuk maupun faktor yang lainnya. Konsumen lebih tertarik menggunakan barang yang bermutu atau memiliki keunggulan lebih tinggi untuk memuaskan kebutuhan dan keinginannya (Saputra et al., 2017). Kualitas memberikan motivasi konsumen untuk loyal terhadap sebuah produk yang dipasarkan produsen (Tjiptono, 2008). Harga adalah elemen penting pada barang, karena berdampak pada omset produsen. Harga turut digunakan sebagai dasar alokasi khusus sebuah produk, penentu keberhasilan produsen. Apabila produsen menentukan harga yang mahal dapat berdampak terhadap produk yang laku di pasar akan sedikit, 
jika jumlah yang ditawarkan murah maka berdampak pada penurunan tingkat keuntungan yang dapat diperoleh perusahaan (Habibah \& Sumiati, 2002). Kotler \& Keller (2009) menyebutkan jika harga merupakan indikator dalam kegiatan pemasaran bukan hanya memastikan tingkat keuntungan, melainkan sebuah tanda atau simbol dalam mempromosikan besarnya manfaat produk barang dan jasa.

Promosi merupakan salah satu permasalahan bagi produsen. Pada produsen khususnya dalam bidang manufaktur, kegiatan iklan atau mengkomunikasikan sebuah produk adalah sebuah metode dalam kegiatan pemasaran produk secara komersial ke tangan ke konsumen dan merupakan factor yang menjadi dasar pertimbangan kesuksesan sebuah kegiatan bisnis untuk mendapatkan pendapatan untuk ekspansi barang dan kontinuitas bisnis yang dijalankan. Pelanggan tidak akan mengetahui atau bersedia mengkonsumsi sebuah produk jika belum memahami manfaat yang diperoleh atas fungsi dan keunggulan dari produk yang dibeli. sehingga, konsumen yang menjadi target produk harus memperoleh data yang akurat dan reliabel (Kurnia, 2016). Promosi merupakan aktifitas yang dijalankan produsen guna mempromosikan keunggulan barang dan jasa serta berfungsi sebagai media untuk mengkomunikasi produk kepada konsumen pada aktifitas jual beli atau pemanfaatan jasa layanan meyesuaikan dengan kebutuhan konsumen (Lupiyoadi, 2013).

Pelayanan yang bermutu memberikan nilai lebih sesuai dengan kebutuhan dan kegiatan evaluasi terhadap keunggulan yang dimiliki terkait dengan upaya menciptakan kepuasan bagi pelanggan (Tjiptono, 2008). Mutu dari jasa yang ditawarkan akan berdampak kepada 2 hal penting, yaitu, jasa yang digunakan dan persepsi konsumen atas jasa yang diberikan. Apabila jasa yang dirasakan tingkat kepyasannya lebih rendah dari ekspectasi konsumen, maka tidak puas terhadap jasa yang ditaerkan, namun jika yang terjadi berlawanan, terdapat peluang konsumen memanfaatkan layanan jasa tersebut. Nilai mutu layanan yang diberikan bukan hanya berdasarkan tolak ukur produsen semata melainkan juga dari sisi konsumen (Rangkuti, 2006). Pelayanan yang bermutu menurut Tjiptono (2008), terkait dengan nilai kelebihan yang diinginkan pelanggan serta evaluasi terhadap jumlah keunggulan yang diharapkan agar mampu memuaskan pelanggan (Widagdo, 2011). Melihat latar belakang diatas maka target penelitian yang dilakukan yaitu untuk mengetahui dampak kualitas barang, jumlah, promosi, dan mutu layanan secara secara terpisah maupun secara bersama-sama pada tahapan pengambilan dasar pertimbangan konsumen kopi untuk menentukan kedai kopi khususnya pada Kabupaten Lumajang.

\section{METODE PENELITIAN}

Bentuk penelitian menggunakan explanatory melalui metode kuantitatif. Subyek penelitian berada di Lumajang. Populasi penelitian adalah tidak ada batasan (infinite population), yaitu jumlah populasi yang tidak bisa ditentukan sebelumnya (uncountable). Penarikan sampling berdasarkan Roscoe (1982 dalam Sugiyono, 2015:164) disebutkan banyaknya responden paling sedikit 10 dikalikan dengan banyaknya variabel penelitian. Responden penelitian sebesar 100 orang responden dengan teknik sampling menggunakan sampling acak sederhana merupakan metode penentuan sampling dari sebuah populasi tanpa berdasarkan karakteristik pertimbangan tertentu (Sugiyono, 2002). informasi penelitian diperoleh dari informasi primer langsung melalui responden melalui kuesioner. Teknik pengujian data adalah uji regresi linier berganda melalui program SPSS 21.00 for windows.

\section{HASIL DAN PEMBAHASAN}

Kuesioner diberikan kepada sekitar 100 responden yaitu konsumen kedai kopi di Lumajang. Dengan kriteria konsumen kedai kopi minimal dua kali datang ke kedai kopi tersebut. Responden penelitian sebanyak 63 laki-laki dan 37 perempuan. Usia 21 - 30 tahun sejumlah 48 reponden, 31 40 tahun sejumlah 36 responden, 41 - 50 tahun sebanyak 16, dan > 50 tahun sebanyak 0 responden. Pendidikan SMA/SMU sejumlah 49 responden, S1 sebanyak 37 responden, S2 sejumlah 14 responden, dan S3 sejumlah 0 reponden. 
Semua bagian pertanyaan (indikator) pada keseluruhan variabel penelitian memperoleh nilai corrected item total correlation dengan angka yang lebih tinggi dari $\mathrm{r}$ tabel sehingga bisa diasumsikan jika jenis pertanyaan untuk menilai masing-masing variabel penelitian bisa dinggap valid. Diperoleh besarnya angka cronbach's alpha dari masing-masing variabel penelitian jumlahnya lebih tinggu dari 0.60 , sehingga jenis pertanyaan yang digunakan sebagai tolak ukur variabel penelitian dianggap telah sesuai syarat reliabilitas atau handal digunakan dalam penelitian Berdasarkan hasil uji diketahui jika keseluruhan variabel yang dimanfaatkan sebagai presiktor pada model regresi memperoleh nilai VIF lebih rendah, apabila keseluruhan terletak di bawah 10 dengan nilai tolerance lebih besar dari 0,1. Kondisi ini menunjukkan jika variabel-variabel independent yang diuji pada penelitian ini tidak memiliki adnya gejala multikolinieritas, yaitu keseluruhan variabel yang diuji bisa dimanfaatkan sebagai variabel yang saling independen.

Hasil pengujian heteroskedastisitas memberikan indikasi tidak memiliki pola tertentu. sehingga model regresi dianggap tidak mempunyai tanda terjadi heteroskedastisitas, yang memiliki makna tidak ada permasalahan dengan menggunakan model ini. Pengujian menggunakan normalitas memberikan indikasi gejala residual menyebar secara dengan normal, kondisi ini terbukti bahwa dengan bentuknya yang simetris, tidak ada kecenderungan kearah kana atau kiri

Tabel 1. Uji Analisis

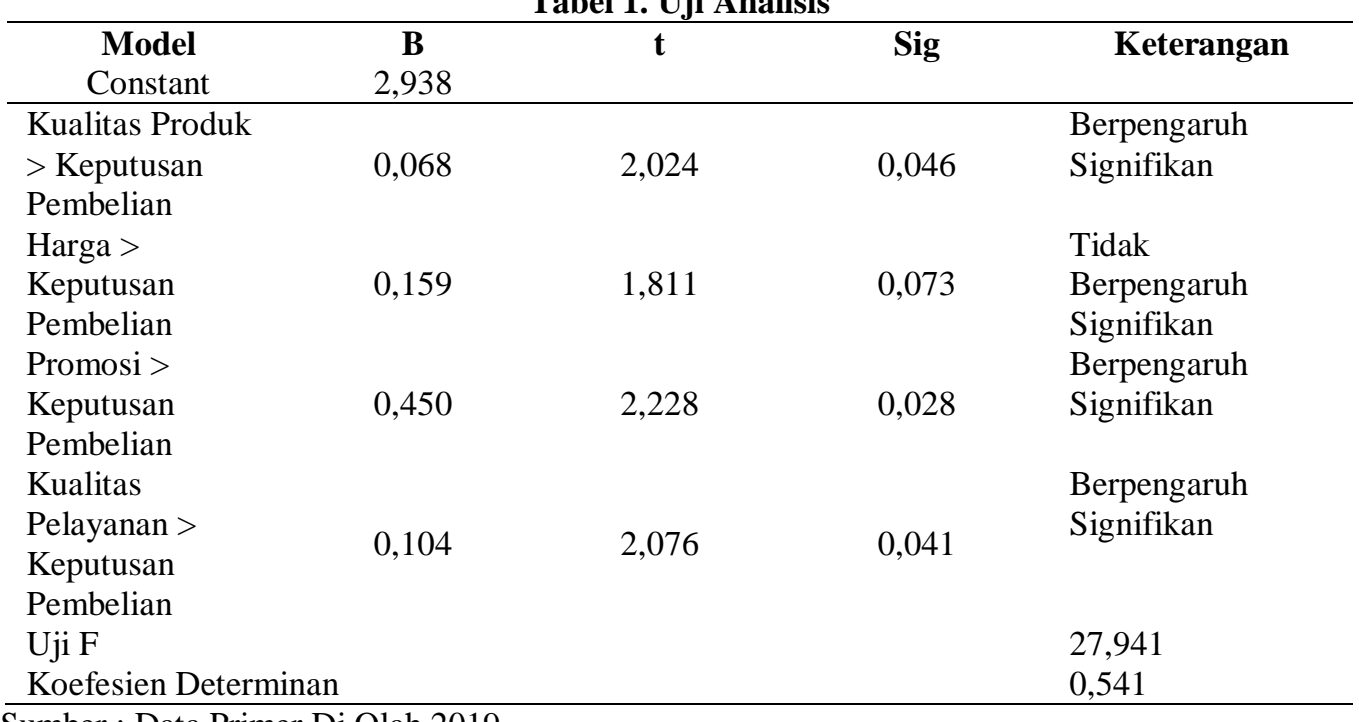

Sumber : Data Primer Di Olah 2019

Pengujian menggunakan analisis regresi linear berganda pada tabel 1 di atas menunjukkan bentuk model garis regresinya yaitu : $\mathrm{Y}=2,938+0,068 \mathrm{X} 1+0,159 \mathrm{X} 2+0,450 \mathrm{X} 3+0,104 \mathrm{X} 4$. Adapun hasil analisis uji t adalah sebagai berikut: Hasil uji signifikansi besarnya tingkat pengaruh mutu produk produk terhadap pengambilan keputusan yaitu $0,046<0,05$, sehingga Ho tidak diterima dan diambil kesimpulan bahwa variabel mutu produk memiliki pengaruh positif signifikan terhadap keputusan pembelian. Hipotesis ke satu mutu produk berpengaruh signifikan terhadap keputusan pembelian terbukti kebenarannya. Pengujian signifikansi besarnya tingkat pengaruh harga terhadap keputusan pembelian, sebesar $0,073<0,05$, memberikan indikasi Ho diterima sehingga disimpulkan bahwa variabel harga tidak memiliki pengaruh positif dan signifikan terhadap pengambilan keputusan pembelian. Hipotesis kedua harga tidak memiliki pengaruh signifikan terhadap pengambilan keputusan pembelian terbukti kebenarannya. Uji signifikansi yang dilkukan menunjukkan pengaruh promosi terhadap keputusan pembelian, dengan besarnya signifikansi variabel promosi $0,028<0,05$ maka Ho tidak diterima dan disimpulkan variabel promosi memiliki pengaruh positif dan signifikan terhadap pengembilan keputusan pembelian. Hipotesis ketiga promosi memiliki pengaruh signifikan terhadap pengambilan keputusan pembelian terbukti kebenarannya. Tingkat signifikansi pengaruh mutu pelayanan terhadap pengambilan keputusan 
pembelian, menunjukkan nilai signifikan variabel mutu pelayanan sebesar $0,041<0,05$ sehingga Ho tidak diterima dan disimpulkan variabel mutu pelayanan memiliki pengaruh positif dan signifikan terhadap pengambilan keputusan pembelian. Hipotesis keempat mutu pelayanan memiliki pengaruh signifikan terhadap pengambilan keputusan pembelian terbukti kebenarannya.

Kegiatan analisis regresi yang dilakukan menunjukkan bahwa nilai signifikan yang diperoleh sekitar $0,000<0,05$ sehingga Ho tidak diterima, hal ini menunjukkan jika teknik yang digunakan untuk menguji besarnya pengaruh mutu produk, harga, promosi dan mutu pelayanan terhadap pengambilan keputusan pembelian dapat dikatakan tepat. Data analisis regresi diperoleh hasil nilai adjusted $R$ Square yang diperoleh adalah sekitar 0,521. Besarnya nilai adjusted $R$ Square tersebut mengindikasikan bahwa besar kontribusi mutu produk, harga, promosi dan mutu pelayanan secara bersama-sama memiliki pengaruh terhadap pengambilan keputusan pembelian adalah sebesar $52,1 \%$, sedangkan nilai sebesar $47,9 \%$ dari nilai Adjusted $R$ Square dipengaruhi oleh variabel lainnya yang belum diuji pada pada penelitian yang dilakukan.

Data hasil analisis mutu produk, harga, promosi dan mutu pelayanan terhadap pengambilan keputusan pembelian kopi menunjukkan bahwa para pembeli kopi akan memutuskan membeli kopi jika konsumen telah merasakan atau mendapatkan informasi terhadap kopi pada kedai kopi tersebut, hal ini menunjukan kualitas produk, promosi dan kualitas pelayanan pada kedai kopi tersebut benar benar membuat konsumen puas sehingga konsumen tanpa ragu lagi datang kembali bahkan merekomendasikan kedai kopi tersebut kepada konsumen yang lain, terutama konsumen pecinta kopi. Karena konsumen yang benar benar pecinta kopi akan mencari dan mendatangi kedai yang dapat mengolah atau meramu serta memiliki kopi yang special. Kopi yang memiliki kekhasan dapat membuat pecinta kopi puas akan kualitas produk kopi. Selain itu kualitas pelayanan dari kedai kopi juga menjadi salah satu penentu konsumen kopi datang kembali ke kedai kopi tersebut. Karena pelayanan yang memuaskan dan tanpa menungu terlalu lama membuat konsumen makin puas dan betah di kedai kopi tersebut. Sedangkan untuk promosi pada kedai kopi cukup dari kualitas produk dan pelayanan yang prima akan secara langsung dan tidak dapat mempromosikan kedai kopi ke konsumen pecinta kopi.

Sedangkan untuk harga terhadap keputusan pembelian kopi menunjukkan jika para konsumen terutama pecinta kopi tidak pernah melihat harga kopi yang disajikan jika konsumen terpenuhi kebutuhannya akan mutu produk kopi dan mutu pelayanan yang diberikan oleh kedai kopi tersebut. Karena harga sifatnya relative, harga dikatakan mahal apabila produk yang dipasarkan tidak tepat dengan produk yang dijual. Sedangkan produk dikatakan murah jika produk yang dijual sesuai dengan mutu produk yang diperoleh konsumen. Bukan hanya itu saja, kualitas pelayanan yang prima juga dapat membuat harga dari suatu produk tidak berarti. Harga yang dikeluarkan konsumen akan dianggao sebanding, apabila pelayanan yang diberikan produsen mampu memberikan kepuasan yang maksimal bagi konsumen. Meskipun kondisinya semacam ini berdasarkan hasil uji tetap diberikan solusi untuk mempertimbangkan mutu produk, harga, promosi dan mutu pelayanan, karena keempat unsur yang digunakan sangat dibutuhkan dalam meningkatkan keputusan pembelian kopi kedai kopi di Kabupaten Lumajang khususnya. Jika ke empat unsur tersebut tidak terpenuhi maka dikhawatirkan akan terjadi penyimpangan dalam keputusan pembelian konsumen, mengingat juga keempat unsur tersebut merupakan variable yang turu berpengaruh terhadap pengambilan keputusan pembelian kopi. Jadi mutu produk, harga, promosi, dan mutu pelayanan harus tetap diperhatikan dalam meningkatkan keputusan pembelian kopi.

Uji hipotesis kedua yang menunjukkan jika mutu produk, harga, promosi dan mutu pelayanan yang memiliki pengaruh positif signifikan secara secara bersama-sama terhadap pengambilan keputusan pembelian kopi di kedai kopi di Kabupaten Lumajang. Hasil analisis menunjukkan bahwa secara bersama-sama mutu produk, harga, promosi dan mutu pelayanan mempunyai pengaruh yang signifikan terhadap pengambilan keputusan pembelian kopi di kedai kopi Kabupaten Lumajang. Data penelitian yang dilakukan sesuai dengan hasil penelitian sebelumnya 
oleh Christy Gerung et al. (2017), Walukow et al. (2016) dan Agustin (2016), dimana secara bersama-sama penelitiannya memberikan indikasi adanya memiliki pengaruh yang signifikan secara positif antara mutu produk, harga, promosi dan mutu pelayanan memiliki pengaruh positif secara signifikan secara simultan terhadap pengambilan keputusan pembelian di kedai kopi Kabupaten Lumajang.

Mengapa secara simultan mutu produk, harga, promosi dan mutu pelayanan memiliki pengaruh positif secara signifikan secara simultan terhadap keputusan pembelian di kedai kopi Kabupaten Lumajang. Sedangkan secara sendiri-sendiril hanya variabel harga yang tidak memiliki pengaruh ? kondisi semacam ini menunjukkan bahwa bagaimanapun pada prinsipya konsumen pecinta kopi di kedai kopi membutuhkan kualitas kopi dan kualitas pelayanan yang baik. Karena kualitas kopi yang sempurna membuat pengunjung atau pecinta kopi itu datang ke kedai kopi yang di tuju dan di senangi. Karena rasa pusa yang di berikan oleh kedai kopi, selain itu kualitas pelayanan kedai kopi terhadap pengunjung atau pecinta kopi juga menjadi salah satu daya tarik dan kepuasan sendiri bagi pecinta kopi. Tak luput dari kedua factor tersebut, suasana kedai kopi dan perbincangan kedai kopi yang telah atau pernah berkunjung ke kedai kopi tersebut, menjadikan salah satu promosi yang tidak terduga dari pemilik kedai kopi. Sehingga pemilik kedai kopi selain memiliki produk yang berkualitas untuk dijual juga harus memperhatikan kualitas pelayanan dan suasana kedai. Oleh karena itu disarankan agar tetap memperhatikan mutu produk, harga, promosi dan mutu pelayanan terhadap pengambilan keputusan pembelian kopi di kedai kopi Kabupaten Lumajang agar lebih baik lagi.

\section{KESIMPULAN}

Berdasarkan dari hasil olah data dengan menggunakan uji mandiri (parsial), menunjukkan bahwa mutu produk, harga, promosi dan mutu pelayanan turut menjadi dasar pertimbangan konsumen dalam melakukan pengambilan keputusan ke sebuah kedai kopi. Semakin besar daya tarik yang diberikan dari masing-masing variabel tersebut, maka akan semakin besar pula keinginan konsumen dari konsumen untuk melakukan pembelian. Dari ke 4 (empat) variabel tersebut ternyata harga yang hasilnya tidak signifikan, hal ini disebabkan karena bagi para pecinta kopi, harga bukan factor penentu utama yang menjadi pertimbangan, jadi bukan hal yang krusial seperti halnya produk yang dijual, jika produk kopinya enak harga bukan menjadi masalah utama. Berdasarkan hasil uji secara bersama-sama (simultan), menunjukkan bahwa mutu produk, harga, promosi dan mutu pelayanan memiliki pengaruh yang besar dalam pengambilan keputusan konsumen ke sebuah kedai kopi. Karena semua variabel tersebut ikut berkontribusi dalam menciptakan stimulus pemilik kedai kopi untuk menarik konsumen agar membeli produk kopi yang dipasarkan.

\section{DAFTAR PUSTAKA}

Agustin, M. Y. (2016). Analisis Kualitas Produk, Harga Dan Promosi Terhadap Keputusan Pembelian Motor Honda Vario (Studi Kasus Pada Tridjaya Motor Dealer Resmi Motor Honda Cabang Girian Â Bitung). Jurnal Berkala Ilmiah Efisiensi, 16(3), 472-483.

Alma, B. (2013). Manajemen Pemasaran dan Pemasaran Jasa. Alfabeta.

Ge, Z., Chen, D., Zhang, J., Rao, J., Yin, J., Wang, D., Wan, X., Shi, W., \& Liu, S. (2007). Facile synthesis of dumbbell-shaped dendritic-linear-dendritic triblock copolymer via reversible addition-fragmentation chain transfer polymerization. Journal of Polymer Science, Part A: Polymer Chemistry, 45(8), 1432-1445. https://doi.org/10.1002/pola.21914

Gerung, C. J., Sepang, J., \& Loindong, S. (2017). Pengaruh Kualitas Produk, Harga Dan Promosi Terhadap Keputusan Pembelian Mobil Nissan X-Trail Pada Pt. Wahana Wirawan Manado. Jurnal EMBA: Jurnal Riset Ekonomi, Manajemen, Bisnis Dan Akuntansi, 5(2), 2221-2229.

Habibah, U., \& Sumiati. (2002). Pengaruh Kualitas Produk Dan Harga Terhadap Keputusan Pembelian Produk Kosmetik Wardah Di Kota Bangkalan Madura. Jurnal Ekonomi, Bisnis \& Entrepreneurship, 1(1), 31-48. 
Kotler, P., \& Amstrong, G. (2016). Prinsip-prinsip Pemasaran. Erlangga.

Kotler, P., \& Keller, K. L. (2009). Manajemen Pemasaran (13th ed.). Erlangga.

Kurnia, M. R. (2016). Pengaruh Merek, Kualitas Produk Dan Promosi Terhadap Keputusan Pembelian Peralatan Olahraga Tenis Meja Oke Sport Di Kecamatan Wonosari. Jurnal Bisnis Dan Ekonomi (JBE), 24(1), 33.

Lupiyoadi, R. (2013). Manajemen Pemasaran Jasa Berbasis Kompetensi (3rd ed.). Salemba Empat.

Malhotra, N. K. (2006). Marketing Research An Applied Orientation. Prestice Hall.

Rangkuti, F. (2006). Teknik Mengukur dan Strategi Meningkatkan Kepuasan Pelanggan. Penerbit PT Gramedia Pustaka Utama.

Saputra, S. T., Hidayat, K., \& Sunarti. (2017). Pengaruh Kualitas Produk Terhadap Keputusan Pembelian Dan Dampaknya Terhadap Kepuasan Konsumen Pengguna Iphone ( Survei pada Mahasiswa Fakultas Ilmu Administrasi Universitas Brawijaya Malang ). Jurnal Administrasi Bisnis, 50(6), 85-95.

Soebakir, B. D., Lumanauw, B., \& Roring, F. (2018). Pengaruh Brand, Harga Dan Kualitas Pelayanan Terhadap Keputusan Pelanggan Membeli Di Kedai Kopi Gudang Imaji Manado. Jurnal EMBA: Jurnal Riset Ekonomi, Manajemen, Bisnis Dan Akuntansi, 6(4).

Sugiyono. (2002). Statistika untuk Penelitian. CV Alfabeta.

Tjiptono, F. (2008). Strategi Pemasaran (3rd ed.). ANDI.

Walukow, A. L. P., Mananeke, L., \& Sepang, J. (2016). Pengaruh Kualitas Produk, Harga, Promosi Dan Lokasi Terhadap Keputusan Pembelian Konsumen Di Bentenan Center Sonder Minahasa. Jurnal EMBA: Jurnal Riset Ekonomi, Manajemen, Bisnis Dan Akuntansi, 2(3), 5-37.

Widagdo, H. (2011). Forum Bisnis Dan Kewirausahaan Jurnal Ilmiah STIE MDP Analisis Pengaruh Kualitas Layanan Dan Promosi Terhadap Keputusan Konsumen Membeli Komputer Pada PT. XYZ Palembang. Jurnal Ilmiah STIE MDP, 1(1), 1-10. http://eprints.mdp.ac.id/303/1/Analisis Pengaruh Kualitas Layanan Dan Promosi Terhadap Keputusan Konsumen Membeli Komputer Pada PT. XYZ Palembang.pdf

Zulaicha, S., \& Irawati, R. (2016). Pengaruh Produk Dan Harga Terhadap Keputusan Pembelian Konsumen Di Morning Bakery Batam. Inovbiz: Jurnal Inovasi Bisnis, 4(2), 123. https://doi.org/10.35314/inovbiz.v4i2.76 